Download

UDC 379.85:791.6:793

https://doi.org/10.17721/2308-135X.2020.59.29-3

$\underline{5}$

Pushka Olga Sergeevna,

Candidate of Technical Sciences, Associate Professor National University of Food Technologies, Kyiv, Ukraine

Sharan Larisa Alexandrovna,

Candidate of Technical Sciences, Associate Professor National University of Food Technologies, Kyiv, Ukraine, e-mail: Larisharan@ukr.net

Arpul Oksana Vladimirovna,

Candidate of Technical Sciences, Associate Professor National University of Food Technologies, Kyiv, Ukraine

Sharan Andrey Vasilyevich,

Candidate of Technical Sciences, Associate Professor National University of Food Technologies, Kyiv, Ukraine 


\section{ETHNIC UKRAINIAN CUISINE AS AN ELEMENT GASTORONOMIC TOURISM IN UKRAINE}

Goal. The purpose of the article is to substantiate the expediency of studying the ancient culture of the Ukrainian people, in particular, acquaintance with the customs and recipes of the ethnographic region in the framework of gastronomic tours throughout Ukraine. After all, statistics show that holding such events inspires young people to study the culture of their ancestors.

Method. The methodological basis of this work are the works of domestic and foreign scientists in the field of hospitality, scientific periodicals, Internet resources. The methodology includes generalizing and statistical data, which reflect the feasibility of gastronomic tourism in Ukraine.

Results. As a result of the research, the national and world experience in teaching young people about cultural values, traditions, local national cuisine by combining recreation and gastronomic tours throughout Ukraine and abroad was analyzed. It was proved the expediency of expanding such national events with the revival of ancient recipes of national dishes of each area and the desire of Ukrainians to maintain and learn about their culture. It is noted that each ethno-region of Ukraine is famous for its local dish: dumplings, brynza, riplyanka, etc., but Ukrainian borscht according to the ancient recipe can be eaten in almost every corner of Kherson and Chernihiv, Poltava, Ivano-Frankivsk, Cherkasy, Lviv, Zhytomyr, Sumy, Vinnytsia, Dnipropetrovsk.

Scientific novelty.

Scientific novelty. The expediency of introduction and expansion of holidays and festivals as an element of gastronomic tourism development is determined. Domestic and world experience in combining travel and learning about national traditions of local cuisine in the form of gastronomic festivals is systematized. It is proved that most of such measures are concentrated in Central and Western Ukraine, as indicated by the obtained statistical facts. 
Practical significance. The materials presented in the paper can be used to improve the regional tourism policy, in particular, for the initiation and expediency of local gastronomic tours and festivals in each region of Ukraine. The launch and holding of gastronomic festivals not only has a positive effect on the image of the territory, but also opens up opportunities for additional impetus to the development of territories and its cultural values.

Key words: national cuisine, traditional dishes, raw materials, gastronomic festivals.

References:

1. World Tourism Organization (UNWTO) Global Report on Food Tourism (2012), p. 63.

2. World Association of Gastronomic Tourism [Electronic resource]. - Access mode: http://www.worldfoodtravel.org.

3. History of nutrition. VI Smolyar. K .: Medicine of Ukraine. $-352 \mathrm{p}$.

4. Wine and gastronomic tourism: global trends and local practices: monograph / [team of authors] for science. ed. D.I. Basyuk. Vinnytsia: PE "Edelweiss and K", 2017. 318 p.

Надійшла до редколегії 23.11.2020 